\title{
CZU:633.111:575 \\ https://doi.org/10.53040/gppb7.2021.71 \\ EFECTELE GENETICE IMPLICATE ÎN RĂSPUNSUL GRĂULUI COMUN LA FILTRATUL DE CULTURĂ Drechslera sorokiniana (SACC.) SUBRAM
}

\author{
Sașco Elena \\ Institutul de Genetică, Fiziologie şi Protecţie a Plantelor, Chișinău, Republica Moldova \\ e-mail: elena.sasco@igfpp.md
}

\begin{abstract}
Helminthosporiosis caused by the fungus Drechslera sorokiniana (Sacc.) causes significant crop and quality losses to Triticum aestivum L. in agroecological conditions with extreme humidity. Increasing the resistance is considered the most cost-effective and sustainable approach to disease control. The aim of this study was to determine the genetic effects involved in the inheritance of resistance, using the genetic model of character reproduction in descendants of wheat. Generations F1, F2, BCP1 and BCP2, descended from the mutual crossing of the parents Basarabeanca / Moldova 30 and Moldova 30 / Moldova 3 (P1 and P2) were evaluated for the response of callus characters to the action of D. sorokiniana culture filtrate on the medium Murashige Skoog. Fungal metabolites have decreased the effects of gene actions and epistatic interactions, but also their variance. The phenomenon corresponds to the decrease of callus indices. A great importance for the heredity of the character of the surface of the callus manifested the epistatic effects of additive-dominant (ad) type. In the case of callus biomass comparable to the mean values were the a actions, but also the ad and dd epistatic effects. The predominant involvement of epistatic effects indicates the need for resistance selections to helminthosporiosis in late generations of wheat.
\end{abstract}

Key words: Triticum aestivum L., heritability, gene effects, $\mathrm{F}_{1}$ and $\mathrm{F}_{2}$ hybrid, reciprocal hybrids, Drechslera sorokiniana culture filtrate, frequency of callus, callus surface area and biomass.

\section{Introducere}

Grâul (Triticum aestivum L.) este cea mai importantă cultură alimentară din lume. Predicțiile asociate cu schimbările climatice globale presupun o pierdere considerabilă a potenţialului productiv, dar și o redistribuție pe scară largă a patogenilor asociați cu complexul de agenți fungici în agro-ecosistemele cerealelor din întreaga lume [5,9].

Drechslera sorokiniana (sinonim Bipolaris sorokiniana (Sacc.)) predomină în structura complexului de patogeni care produce putrezirea timpurie a plantulelor și brunificarea frunzelor, putregaiul comun de rădăcină și rozetă, dar și embrionul negru la grâu în multe regiuni, îndeosebi în condiţii extreme de umiditate $[1,3]$. În componența agenților patogeni ai putregaiului de rădăcină și tulpină la grâul comun de toamnă în condițiile Republicii Moldova, dar și a Câmpiei din China de Nord a fost depistată cu cea mai înaltă frecventă coexistența simultană a speciilor patogene Fusarium spp. și D. sorokiniana [6, 9]. Creșterea frecvenței de distribuție spațială, cât și a patogenității fungului D. sorokiniana este explicabilă prin prezența pigmentului de melanină în celulele fungului, care permite organismelor melanizate să existe în condiții extreme cu insolație crescută, uscăciune și temperaturi ridicate și, de asemenea, previne liza miceliului acestor organisme [4].

Modalitatea cea mai eficientă în gestionarea pierderilor cauzate de helmintosporioze la cereale constituie creșterea rezistenței gazdei. În menținerea sănătății ecosistemului precum și obținerea rezistenței durabile, de o importanță majoră se impun abordările genetice și ecologice $[4,6,7,9]$. Brunificarea frunzelor cauzată de $B$. sorokiniana determină randamente și pierderi de calitate semnificative în condițiile agroecologce calde și umede ale lumii. Predominanța efectelor genetice aditive în procedeele de selecție recurentă sugerează că strategia ar putea stimula rezistența la maladie în populațiile generațiilor timpurii [8]. Evaluarea tipurilor de acțiune genetică care guvernează moștenirea rezistenței la necroza Phytophthora nicotianae în populațiile de ardei a înregistrat efecte aditive și dominante semnificative pentru izolatele, care au prezentat o agresivitate scăzută. Pe când, pentru izolatele mai agresive epistaziile au manifestat o pondere majoră a rezistenței. Amplitudinea epistaziilor a fost mai importantă în grâul durum nu numai în dependență de agresivitatea patogenului Septoria tritici, dar și de stadiul de dezvoltare a 
frunzelor. Autorii concluzionează că epistaziile joacă un rol crucial în adaptabilitatea genetică a plantelor la condiții climatice de stres biotic sau abiotic [2].

În acest context prezintă interes mecanismele eredităţii care guvernează moștenirea rezistenței în răspunsul grâului comun de toamnă la patogenul $D$. sorokiniana cu scopul de a stabili metodele de selecţie pentru rezistență la helmintosporioze.

\section{Materiale și metode}

Pentru a stabili controlul genetic al însușirilor de calusogeneză în răspunsul grâului comun de toamnă la filtratul de cultură $(\mathrm{FC})$ D. sorokiniana au fost investigate populațiile $\mathrm{F}_{1}, \mathrm{~F}_{2}, \mathrm{BC}_{1}$ și $\mathrm{BC}_{2}$, obținute din încrucișarea reciprocă a genotipurilor $\mathrm{P}_{1}$ și/sau $\mathrm{P}_{2}-$ Basarabeanca / Moldova $30(\mathrm{~B} / \mathrm{M})$ și Moldova 30 / Moldova $3(\mathrm{M} / \mathrm{M})$. Filtratul de cultură $D$. sorokiniana s-a preparat în baza mediului lichid Cszapek, fiind administrat în concentraţie de $25 \%$ de volum în mediul Murashige-Scoog (MS). Seminţele au fost sterilizate la suprafaţă cu etanol de $96 \%$, apoi cu soluţie de clorură de calciu, clătite şi pregerminate la $28-30^{\circ} \mathrm{C}$. Meristemul apical excizat din embrionul matur a fost plasat pe mediul nutritiv MS, care conținea un set complet de macro și microelemente, vitamine, acidul 2,4-diclorfenoxiacetic (2,4-D) 2 mg/l, mezo-inozitol 100 mg/l, zaharoză 30 g/l şi agar-agar 7 g/l, pH-ul fiind ajustat la 5,8. Frecvenţa de calusare (\%), suprafaţa $\left(\mathrm{mm}^{2}\right)$ şi masa brută a calusului $(\mathrm{mg})$ au fost înregistrate la 21 zile de cultură. Efectele acţiunilor genelor implicate în ereditatea caracterelor menţionate au fost calculate în baza modelului de analiză genetică aplicat de Gamble (1962), model care permite descompunerea efectelor genetice prin împărţirea mediei populaţiilor şi evaluarea acţiunilor genice aditive $(a)$, dominante $(d)$ şi a celor epistatice datorate interacţiunilor interalelice de tipul aditiv $x$ aditiv (aa), aditiv $x$ dominant $(a d)$ şi dominant $x$ dominant $(d d)$, precum şi stabilirea semnificaţiei acestora cu ajutorul varianţelor corespunzătoare. Nivelul, orientarea și varianţa caracterelor cercetate au fost analizate în pachetul de soft STATISTICA 7.

\section{Rezultate și discuții}

În varianta martor în generația hibridă $F_{1}$ a fost manifestată supradominanţa, sau dominanța parţială pentru suprafața calusului, dar și dominanță parţială - în cazul biomasei calusului. Heterozisul pozitiv faţă de cel mai bun părinte în cazul fenotipului suprafața calusului a fost valorificat la implicarea efectului matern al genitorului Basarabeanca / Moldova 30 (4.3\% și 1.4\%). Rata transgresiilor estimate în generația $F_{2}$ sugerează că doar în combinația Moldova 30 / Moldova 3 x Basarabeanca / Moldova 30, deci la implicarea genitorului patern Basarabeanca / Moldova 30 există probabilitatea de apariţie a unor linii cu valoare transgresivă pentru caracterele suprafața calusului (10,7\%), dar și biomasa calusului (6,6\%).

Indicii de calusare au fost diminuați diferențiat în răspunsul la agentul patogen $D$. sorokiniana. Hibrizii generației $F_{1}$ au manifestat valori intermediare, dar și mai joase celor obținute de părinţi, fiind estimată dominanţa parțială, dar și supradominanța părintelui cu valorile joase ale caracterului $(\mathrm{h}=-0.5 \ldots$... 1.3), totodată și lipsa heterozisului. În generația hibridă $F_{2}$ a fost atestată rezistență la FC D. sorokiniana pentru indicii suprafața calusului și biomasa calusului. Rata transgresiilor favorabile, calculată din distribuţia normală a caracterului suprafaţa calusului a înregistrat $4.1 \%$, precum și $9.0 \%$ - în cazul biomasei calusului. Segregarea transgresivă indică prezenţa relaţiilor nealelice. Fenomenul confirmă implicarea genitorului matern Basarabeanca / Moldova 30 în valorificarea caracterelor în cazul răspunsului hibrizilor $\mathrm{F}_{2}$ la metaboliții patogenului D. sorokiniana (Fig.1).

În tabelul 1 sunt prezentate efectele acţiunilor genice implicate în moștenirea rezistenţei la FC $D$. sorokiniana. În varianta martor precum și în răspunsul la FC D. sorokiniana majoritatea efectelor sunt semnificative. Sub influența FC acțiunea efectelor genetice a diminuat ca valoare și direcție, cu excepția atestată în cazul epistaziilor $d d$. Metaboliții fungici au condus la schimbarea direcției efectelor acțiunilor și interacțiunilor genice, ceea ce corespunde diminuării mediilor suprafaței calusului. Efectele genice $a$, dar și a interacțiunilor $a d$ în combinația $\mathrm{B} / \mathrm{M}$ x M/M sunt semnificative şi cu valori pozitive, mărimea acestor efecte indicând că ele sunt de o importanţa ridicată pentru ereditatea caracterului suprafața calusului. În cazul hibridului reciproc $\mathrm{M} / \mathrm{M}$ x B/M caracterul dat este favorizat, corespunzător mediilor, atât de acțiunile genice $a$ și $a d$, precum și de efectele interalelice $d d$. 


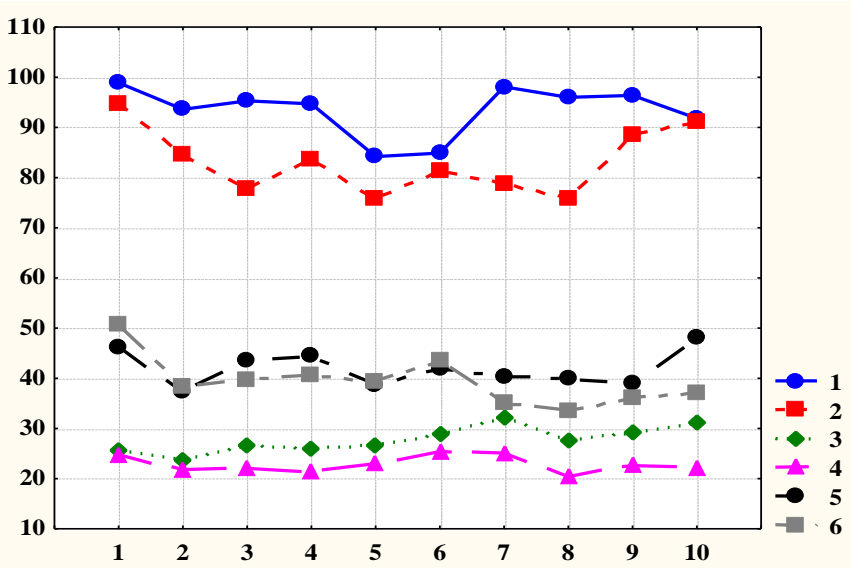

Fig.1. Manifestarea caracterelor de calusogeneză la descendenții combinației reciproce Basarabeanca/ Moldova 30 x Moldova 30/Moldova 3

Pe verticală: 1, 2 - Frecvența de calusare (\%); 3, 4 - Suprafaţa calusului $\left(\mathrm{mm}^{2}\right)$;

5, 6 - Biomasa calusului (mg); 1, 3, 5- Martor; 2, 4, 6 - FC D. sorokiniana;

Pe orizontală: 1 - B/M 30; 2 - M 30/M 3; 3, $5-\mathrm{F}_{1}, \mathrm{~F}_{2}$ B/M 30 x M 30/M 3;

4, $6-\mathrm{F}_{1}, \mathrm{~F}_{2} \mathrm{M} 30 / \mathrm{M} 3$ x B/M 30; 7, 8 - BC1, BC2 B/M 30 x M 30/M 3 ;

$9,10-\mathrm{BC}_{1}, \mathrm{BC}_{2} \mathrm{M} 30 / \mathrm{M} 3 \times \mathrm{B} / \mathrm{M} 30$;

Tabelul 1. Efectele genice implicate în ereditatea caracterelor calusogenezei la acțiunea filtratului de cultură D. sorokiniana (Sacc.) Subram.

\begin{tabular}{|l|l|l|l|l|l|l|}
\hline Varianta & mediu & a & d & aa & ad & \multicolumn{1}{c|}{ dd } \\
\hline \multicolumn{7}{|c|}{ Suprafața calusului, B/M x M/M } \\
\hline Martor & $26.5 \pm 0.9^{* *}$ & $4.6 \pm 1.0^{*}$ & $15.5 \pm 0.9^{* *}$ & $13.3 \pm 0.9^{*}$ & $29.3 \pm 0.9^{* *}$ & $-29.6 \pm 0.9^{* *}$ \\
\hline FC & $23.0 \pm 0.9^{* *}$ & $4.7 \pm 0.8^{*}$ & $-2.2 \pm 0.8^{*}$ & $-0.9 \pm 0.8$ & $28.0 \pm 0.8^{*}$ & $0.6 \pm 0.8$ \\
\hline \multicolumn{7}{|c|}{ Suprafața calusului, M/M x B/M } \\
\hline Martor & $29.0 \pm 1.0^{* *}$ & $1.7 \pm 0.8^{*}$ & $6.4 \pm 0.9^{* *}$ & $5.0 \pm 1.0^{*}$ & $26.4 \pm 0.8^{* *}$ & $-24.6 \pm 0.9^{* *}$ \\
\hline FC & $25.4 \pm 0.7^{* *}$ & $-0.3 \pm 0.7$ & $-13.9 \pm 0.7^{* *}$ & $-12.0 \pm 0.7^{* *}$ & $23.0 \pm 0.7^{* *}$ & $11.9 \pm 0.7^{* *}$ \\
\hline \multicolumn{7}{|c|}{ Biomasa calusului, B/M x M/M } \\
\hline Martor & $38.8 \pm 1.3^{* *}$ & $0.3 \pm 1.5$ & $7.2 \pm 1.4^{* *}$ & $5.4 \pm 1.4^{*}$ & $42.2 \pm 1.5^{* *}$ & $5.2 \pm 1.4^{*}$ \\
\hline FC & $39.5 \pm 1.2^{* *}$ & $1.3 \pm 1.6$ & $-28.1 \pm 1.4^{* *}$ & $-20.6 \pm 1.4^{* *}$ & $45.8 \pm 1.6^{* *}$ & $46.2 \pm 1.5^{* *}$ \\
\hline \multicolumn{7}{|c|}{ Biomasa calusului, M/M x B/M } \\
\hline Martor & $41.8 \pm 1.6^{* *}$ & $-9.1 \pm 1.5^{* *}$ & $9.6 \pm 1.6^{* *}$ & $7.0 \pm 1.6^{*}$ & $32.7 \pm 1.4^{* *}$ & $-8.3 \pm 1.5^{*}$ \\
\hline FC & $43.6 \pm 1.7^{* *}$ & $-1.0 \pm 1,7$ & $-31.5 \pm 1.7^{* *}$ & $-27.8 \pm 1.7^{* *}$ & $43.4 \pm 1.7^{* *}$ & $51.5 \pm 1.7^{* *}$ \\
\hline
\end{tabular}

Acțiunile $a, d$ și interacțiunile genice $a a, a d$ au manifestat valori superioare în variantele martor și FC D. sorokiniana pentru $\mathrm{B} / \mathrm{M} \times \mathrm{M} / \mathrm{M}$ în raport cu hibridul reciproc, fiind atestat suportul genitorului matern $\mathrm{B} / \mathrm{M}$ atât în producerea caracterului (martor), dar și în manifestarea rezistenței la FC D. sorokiniana. Valori superioare ale indicelui biomasa calusului în răspunsul la FC D. sorokiniana au fost atestate la acţiunea forțelor aditive $a$ și a interacțiunilor genice $a d$ și $d d$. În moștenirea caracterelor suprafața și biomasa calusului la acțiunea FC D. sorokiniana au fost atestate cu o ponderea înaltă efectele interacțiunilor epistatice.

\section{Concluzii}

Filtratul de cultură D. sorokiniana a influențat diferențiat moștenirea caracterelor de frecvență, suprafață şi biomasă a calusului la descendenţii grâului comun de toamnă.

Metaboliții fungici au condus la schimbarea valorică și a direcției acțiunilor și interacțiunilor genice, cea ce corespunde diminuării mediilor suprafața calusului. Efectele interalelice $a d$, atestate în ambele combinaţii, influențează corespunzător reacția indicelui la acțiunea fungului D. sorokiniana. 
Valori superioare ale caracterului biomasa calusului în răspunsul la Drechslera sorokiniana au fost atestate la acțiunea forțelor aditive și a interacțiunilor genice $a d$ și $d d$.

Implicarea predominantă a efectelor epistatice în moștenirea caracterelor indică necesitatea selectărilor pentru rezistență la helmintosporioze în generații târzii.

Cercetările au fost realizate în cadrul proiectului Programului de Stat 20.80009.7007.04 "Biotehnologii și procedee genetice de evaluare, conservare și valorificare a agrobiodiversităţii”, finanţat de Agenţia Națională pentru Cercetare și Dezvoltare.

\section{Bibliografie}

1. AL-SADI, A.M. Bipolaris sorokiniana-Induced Black Point, Common Root Rot, and Spot Blotch Diseases of Wheat: A Review. In: Front Cell Infect Microbiol., 2021. doi: 10.3389/fcimb.2021.584899.

2. BNEJDI, F., COLIN, H., EL GAZZEH, M. Genetic adaptability of inheritance of resistance to biotic and abiotic stress level on crop: Role of epistasis. In: African Journal of Biotechnology, 2011. Vol. 10(86), pp. 1991319917. DOI: 10.5897/AJBX11.067 ISSN 1684-5315.

3. BURLAKOTI, R.R., SHRESTHA, S.M., SHARMA, R.C. Impact of seedborne inoculum, irrigation, and cropping pattern on propagation of Bipolaris sorokiniana and epidemiology of foliar blight and common root rot in spring wheat. In: Journal of Plant Pathology, 2013. Vol. 95(3), pp. 571-578.

4. CHAUHAN, P.K., SINGH, D.P., KARWASRA, S.S. Morphological and Pathogenic Variability in Bipolaris sorokiniana Causing Spot Blotch in Wheat (Triticum aestivum, T. durum, T. dicoccum) in India. In: Int. J. Curr. Microbiol. App. Sci., 2017. Vol. 6(11), pp. 3499-3520. doi.org/10.20546/ijcmas.611.412.

5. KUMAR, P., RAI, R.C. Spot blotch: A threat to wheat in changing climate-an overview. Journal of Pharmacognosy and Phytochemistry, 2019. Vol. 8(2), pp. 326-331.

6. LUPAȘCU, G., SAȘCO, E., GAVZER, S. ș.a. Controlul genetic al caracterelor de rezistență și productivitate la grâul comun. Chișinău: Tipografia Centrală. 2015. 174 p.

7. SHIKHA. D. et al. Characterization of elite bread wheat (Triticum aestivum L.) germplasm for spot blotch Bipolaris sorokiniana (Sacc.) Shoemaker resistance. In: Plant Genetic resources, 2021. Vol. 18(6), pp. 462 - 469. DOI: https://doi.org/10.1017/S1479262120000490

8. TEMBO, B. et al. Genetic effects of resistance to spot blotch in selected wheat genotypes. In: J. Plant Breed. Genet., 2018. Vol. 6(1), pp. 33-38.

9. XU, F. et al. Spatial Distribution of Root and Crown Rot Fungi Associated With Winter Wheat in the North China Plain and Its Relationship With Climate Variables. In: Front Microbiol., 2018. Vol. 9, pp. 1054. doi: 10.3389/fmicb.2018.01054 